\title{
ADENOSARCOMA MULLERI ASSOCIATED WITH TAMOXIFEN USE AFTER BREAST CANCER THERAPY: A CASE REPORT
}

Neda Arsenijevic ${ }^{1}$, Tatjana Kastratovic ${ }^{2}$, Aleksandar Zivanovic ${ }^{1,2}$, Janko Djuric ${ }^{1,2}$, Marija Sorak ${ }^{1,2}$ ${ }^{1}$ Clinic of Gynecology, Clinical Centar Kragujevac, Kragujevac, Serbia

${ }^{2}$ Department of Gynecology, Faculty of Medical Sciences, University of Kragujevac, Kragujevac, Serbia

\author{
MILEROV ADENOSARKOM UTERUSA \\ - UDRUŽENOST SA UPOTREBOM TAMOKSIFENA NAKON LEČENJA \\ KARCINOMA DOJKE-PRIKAZ SLUČAJA

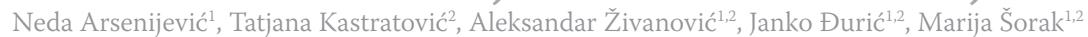 \\ ${ }^{1}$ Klinika za ginekologiju, Klinički centar Kragujevac, Kragujevac, Srbija \\ ${ }^{2}$ Katedra za ginekologiju, Fakultet medicinskih nauka, Univerzitet u Kragujevcu, Kragujevac, Srbija
}

Received / Primljen: 04.07.2015

Accepted / Prihvaćen: 31.08.2015

\section{ABSTRACT}

The term 'mixed Müllerian tumour' applies to uterine tumours composed of epithelial and mesenchymal elements of Müllerian origin. These neoplasms are classified into adenomyomas, adenofibromas, adenosarcomas, and carcinosarcomas (malignant Müllerian mixed tumours) based on whether the epithelial and stromal elements are benign or malignant. Adenosarcomas are low-grade neoplasms classified halfway along the spectrum of mixed Müllerian tumours, with adenofibromas at one end and carcinosarcomas (malignant Müllerian mixed tumours) at the other. Adenosarcoma is a mixed Müllerian tumour composed of benignappearing but neoplastic glandular elements and a sarcomatous stroma, which is usually low grade. Histologically, there are heterologous mesenchymal elements (usually rhabdomyosarcoma, but also cartilage, fat, and other elements) in 20-25\% of cases.

We have observed that some women with these tumours have received tamoxifen treatment for breast cancer or have a history of radiation therapy.

We herein report the case of a 46-year-old patient who was hospitalized at OGC CC Kragujevac because of excessive bleeding from the uterus. The patient had undergone right mastectomy three years earlier for breast cancer. After surgery, she had received Nolvadex (tamoxifen) treatment. Exploratory curettage was performed, and then, a classic abdominal hysterectomy with bilateral adnexectomy was completed. The histopathological findings indicated adenosarcoma Mülleri; therefore, the patient received postoperative radiation therapy according to our current protocol.

Keywords: adenofibroma; adenosarcoma; carcinosarcoma; malignant Müllerian mixed tumour;

\section{SAŽETAK}

Termin mešani Milerov se odnosi na tumore uterusa sastavljene od epitelijalnih $i$ mezenhimalnih elemenata porekla Milerovih kanala. Ove neoplazme su klasifikovane u adenomiome, adenofibrome, adenosarkome $i$ karcinosarkome (maligni Milerovi mešani tumori), zavisno od toga da li su epitelijalne i stromalne komponente benigne ili maligne.

Adenosarkomi su neoplazme niskog gradusa zrelosti klasifikovane negde na pola spektra mešanih milerovih tumora, sa adenofibromima na jednoj $i$ karcinosarkomima (malignim Milerovim mešanim tumorima) na drugoj strani. Adenosarkom je mešani Milerov tumor sastavljen od neoplastičnih glandularnih elemenata ali benignog izgleda $i$ sarkomatozne strome, koja je obično niskog gradusa.

Često ga dijagnostikujemo kod pacijentkinja koje su primale terapiju Tamoxifenom za lečenje karcinoma dojke ili su imale zračnu terapiju. U vreme dijagnoze, većina tumora je ograničena samo na uterus (Stadijum I). U histološkoj slici heterologi mezenhimalni elementi (obično rabdomiosarkom, ali takođe $i$ hrskavica, masno tkivo $i$ drugi elementi) su prisutni u oko 20-25\% slučajeva.

Prikazana je četrdesetšestogodišnja pacijentkinja koja je hospitalizovana u GAK KC Kragujevac zbog obilnog krvarenja iz materice, a pre tri godine joj je odstranjena desna dojka zbog karcinoma nakon čega je bila na terapiji Nolvadexom/Tamoxifenom. Nakon eksplorativne kiretaže a zatim $i$ klasične abdominalne histerektomije sa obostranom adnexectomijom dijagnostikovan je Milerov adenosarkom te je pacijentkinja primila i postoperativnu zračnu terapiju prema važećim protokolima.

Ključne reči: adenofibrom; adenosarkom; karcinosarkom; maligni Milerov mešani tumor; 


\section{INTRODUCTION}

Uterus Müllerian adenosarcoma is a rare gynaecological malignant tumour.

It is composed of epithelial and mesenchymal elements of Müllerian origin. This rare tumour, which represents $2-5 \%$ of all uterine tumours, i.e., approximately $8 \%$ of all uterine sarcomas, usually originates from the endometrium and grows as a polypoid mass inside the cavum (1). The uterine body is most often affected, but this tumour is also common on the cervix and ovaries and, more rarely, in the vagina and fallopian tubes. Its origin can also be the peritoneal surface or even outside of the genital system, such as in the intestines (2).

The histological findings are characterized by benign, sometimes mildly atypical glandular epithelial elements associated with malignant stromal changes, which are characterized by specific structures of "periglandular cuffing" with increased cellularity and intraglandular polyps. The stroma is usually characterized by increased cellularity around epithelial elements, which leads to the formation of a cambium layer. The stromal component is commonly of low morphological grade and consists of endometrial stroma or fibroblasts (that are hormone receptor- and CD10-positive) (3). It may occasionally be of high grade, and this represents an unidentified sarcoma (4). Adenosarcomas of the uterus are generally neoplasms of low grade, are capable of recidivism after polypectomy or hysterectomy and are only very rarely metastatic. The two most important negative prognostic factors, which are occasionally present, are deep miometric invasion with a predominant sarcomatous component and high morphological grade, which is followed by the loss of hormone receptors and CD10. Adenosarcoma can be mistaken for various lesions, and the main differential diagnosis is adenofibroma, which by definition has a morphologically benign component (5).

The main symptom of these lesions is abnormal vaginal bleeding, pain in the lower abdomen, a palpable tumour mass in the lower abdomen, unusual urinary symptoms, increased and prolonged vaginal discharge, and sometimes the presence of polypoid tissue that can be seen in a dilated cervical canal (14). These tumours have a tendency to appear in postmenopausal patients with an average age of 66 years. The average time interval from the first symptoms to the final diagnosis is approximately 13 months. The risk factors are similar to those of uterine adenosarcoma and include obesity, oestrogen therapy, radiation exposure, nulliparity, and potentially tamoxifen exposure (7). The prognosis is much better in the early phase and in younger patients, although these are often incorrectly treated due to an incorrect diagnosis (6). The usual treatment is surgical resection, which consists of total abdominal hysterectomy with bilateral salpingooophorectomy, along with the application of broad-spectrum antibiotics, followed by postoperative radiation of the pelvis $(15,16,17)$.

\begin{tabular}{|l|l|}
\hline Stage I & Carcinoma is limited to the body of the uterus \\
\hline Stage II & Carcinoma affects the body and the cervix of the uterus \\
\hline Stage III & $\begin{array}{l}\text { Carcinoma has spread outside of the uterus but not out- } \\
\text { side of the small pelvis }\end{array}$ \\
\hline Stage IV & $\begin{array}{l}\text { Carcinoma has spread outside of the small pelvis and af- } \\
\text { fects the bladder or rectal mucosa }\end{array}$ \\
\hline
\end{tabular}

Table 1. The tumour staging

Adenosarcomas are low-grade neoplasms, which are classified somewhere in the middle of the mixed Müllerian tumours, with adenofibromas on one side and carcinosarcomas (malign mixed Müllerian tumours) on the other. Adenosarcoma generally has a worse prognosis than endometrial carcinoma, with a five-year mortality rate in the range of $5 \%$ up to $40 \%$. However, the total mortality rate is less than $20 \%(18,19)$. The key prognostic factor is the stage of the disease at the time of the diagnosis (Table 1)(15).

Lifelong tracking of these patients is necessary because of the high risk of recurrence, mainly in the cases with myometrial invasion (12).

Adenosarcoma Mulleri is a metaplastic carcinoma that represents a subtype of uterine sarcoma. The subsidiary oncological therapy is similar to that applied for cases of highly malignant uterine sarcoma, such as leiomyosarcomas and unidentified sarcomas $(17,19)$. It has been shown that most uterine adenosarcomas are monoclonal neoplasms and are actually metaplastic carcinomas. The behaviour of the uterine adenosarcomas is more like that of the endometrioid type of endometrial adenocarcinoma and the aggressive subtypes of uterine carcinoma. The sarcomatic component derives from carcinomatous elements, which are the driving forces. It is currently unclear whether adenosarcoma begins as a carcinoma in transition through sarcomatous transdifferentiation or as a sarcoma in transition through epithelial transdifferentiation (13).

There is increasing evidence in the literature that this tumour is associated with tamoxifen therapy for the treatment of breast cancer $(8,9,10)$. At the time of the diagnosis, most of the tumours are limited to the uterus (Stage I) (11).

Prolonged oestrogen or androgen exposure can lead to the development of mesenchymal and mixed epithelialmesenchymal uterine tumours.

There are both homologous and heterologous types of adenosarcoma. In patients with the homologous type, the sarcoma component is in the uterine tissue, such as the endometrium, fibroid tissue or lean muscle tissue. The heterologous type is characterized by elements of rhabdomyosarcoma, chondrosarcoma or osteosarcoma (14).

It has been noted that in the adenosarcoma cases, PI3K signalling mutations are common, which are generally present before the tumour transdifferentiation and metastasis, providing considerable support for applying treatments targeting PI3K signalling in most cases of uterine adenosarcoma $(4,6)$. 


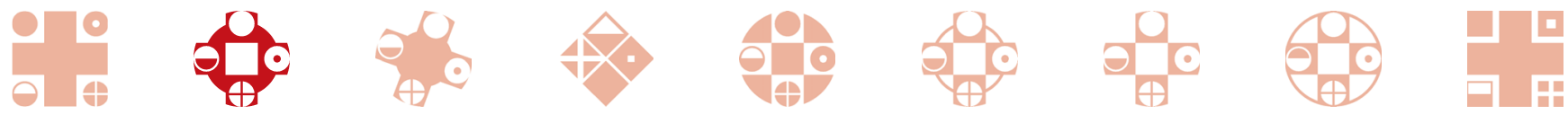

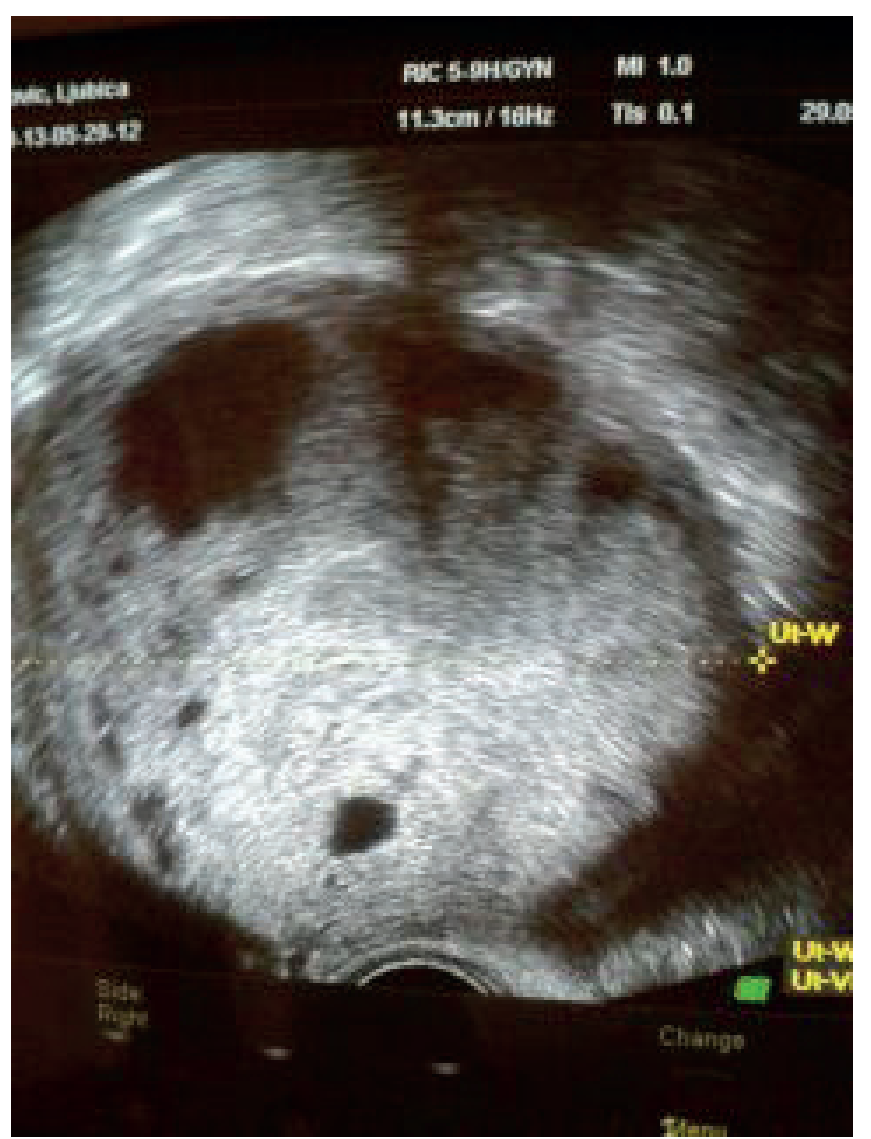

Image 1. The US presentation of the uterus (transverse section), with a hypoechoic tumour mass that filled the entire uterine cavum

\section{CASE STUDY}

We herein report the case of a 46-year-old patient who was hospitalized at OGC CC Kragujevac because of excessive bleeding from the uterus. The patient reported having stopped menstruation three years earlier, had regular and normal periods prior to that, had undergone one $\mathrm{C}$-section and had terminated one pregnancy. She was suffering from Raynaud syndrome, and her right breast had been removed three years earlier because of breast cancer. After the mastectomy, she was administered Nolvadex (tamoxifen) therapy.

Irregular bleeding had appeared one month prior, which was treated by exploratory curettage of the uterus. Eighteen days later, the patient was sent to OGC CC Kragujevac for the same symptom (without any histopathological information).

The patient was thoroughly examined in our department. The results of the lab analysis were Le, 7.5; Er, 4.28; HGB, 136; Hct, 0.394; Plt, 269; PTs, 10.3; INR, 0.906; PT\%, 122.3; Fib, 1.908; APTT, 22.9; glucose, 9.3; urea, 4.1; creatinine, 62; K, 4.2; Na, 139; urine, without irregularities; Troponin I, 0.002; CEA, 0.7; AFP, 9.39; CA125, 59; CA19-9, 7.1; B-HCG, 0.60; $\mathrm{TSH}, 1.54$ and fT4, 11.86. She was blood group $\mathrm{O}$ and $\mathrm{Rh}+$.

The ultrasound (US) findings showed that the uterus was in the AVF and had dimensions of $121 \times 91 \times 91 \mathrm{~mm}$ with the cavum filled with hyperechoic contents and a thickness of $75 \mathrm{~mm}$. Of note, the described changes did

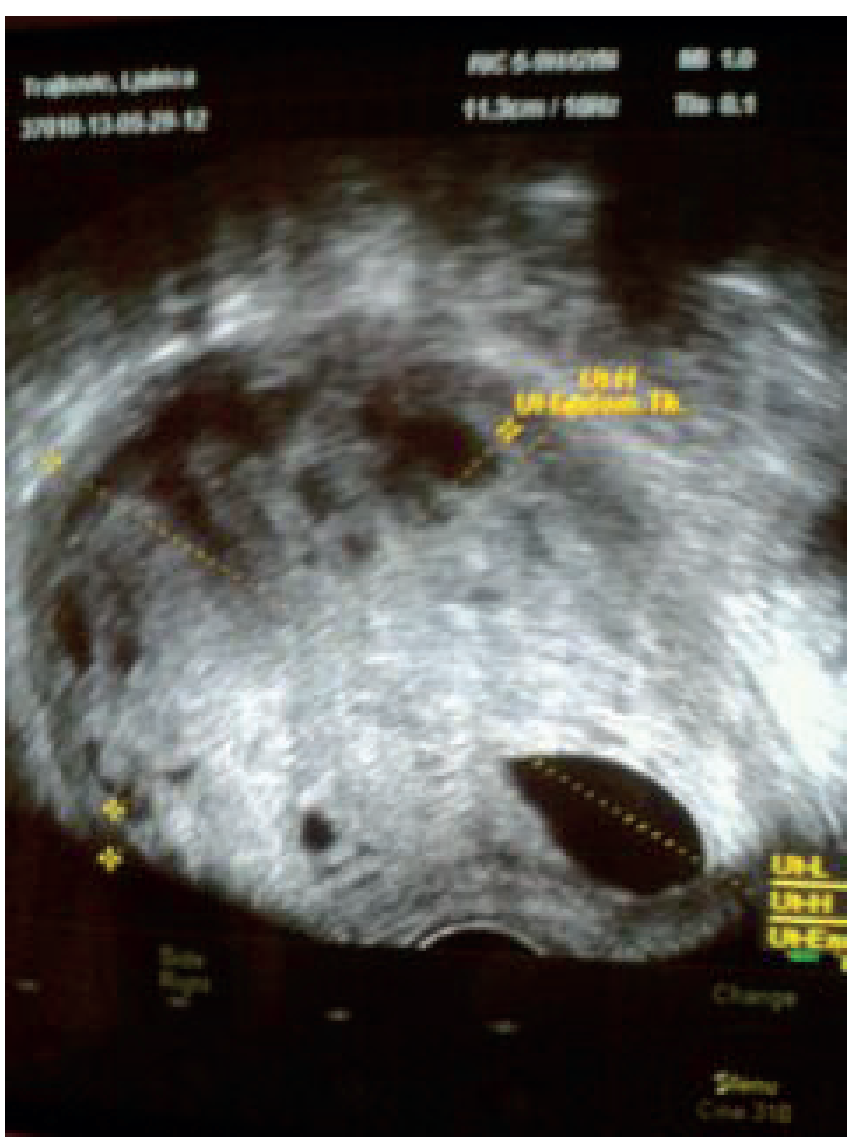

Image 2. The US presentation of the uterus (longitudinal section), with the tumour mass in the cavum, which had a thickness of $75 \mathrm{~mm}$, while the myometrium had a thickness of $6 \mathrm{~mm}$.

not penetrate the myometrium, which had a thickness of 6 $\mathrm{mm}$. Neither of the ovaries had any pathological changes. The Pouch of Douglas was empty.

Following repeated exploratory curettage, the material obtained was sent for a histopathological analysis, but the pathologists were unable to determine an exact diagnosis. The material was therefore sent to Belgrade for a histopathological analysis.

The results of the Kreitman test showed a malignant tumour with short, round and somewhat elongated cells, a basophilic cytoplasm, irregular cells, and pseudobeam-like fields. The was clear chondroid differentiation. There were individual, partly klef-like, glandular benign structures inside the stroma, which were $\mathrm{ER}+/ \mathrm{PR}+$. The immunophenotype of the tumour was CD10+/-/Desmin- or only focally/Actin-pan- or only focally /SMA-/CD99- or focally /C-kit- or focally/S-100-Er-/Pr-/Myogenin and MyoD1 only in one group of nuclei. The mitotic count was 8/10 HPF; the Ki 67 index was high at 40\%.

Based on these findings, we concluded that the patient had a malign tumour with predominant sarcomatous stroma, benign endometrial glands, and imaging findings characteristic of adenosarcoma Mülleri with elements of heterologous differentiation (chondroid and rhabdomyoblastic). We eventually concluded that the tumour was an 
endometrial sarcoma with heterologous differentiation that was associated with glandular proliferation. The patient was treated with intensive antibiotic therapy. After consulting with pathologists, it was decided that the patient should undergo hysterectomy with bilateral adnexectomy (salpingo-oophorectomy).

After obtaining the patient's consent, the surgery was performed. During the operation, we noted that size of the uterus was large, equivalent to that of two fists, with a smooth and neat surface and without macroscopically noticeable pathological changes on the serosa. The fallopian tubes were clear though the whole distance, the ovaries were of normal size, appearance and position. The omentum had a normal appearance and size, without any noticeable pathological changes. The peritoneum of the small pelvis was normal, with no accumulation of fluid in the abdomen, or any other pathological changes.

Classical hysterectomy with bilateral adnexectomy was performed. The tissues were sent for a histopathological analysis. The abdominal wall was closed layer by layer, with the skin sewn with individual seams.

The results of the histopathological analysis were Adenosarcoma Mulleri-heterologous type. The sarcoma component comprised $80 \%$ of the tumour, with chondrosarcoma elements, as well as a $10 \%$ leiomyoma component and a field of endometrial sarcoma, with a low degree of malignancy. Areas of bleeding and necrosis were present in the tumour tissue, and there were signs of blood and lymphatic vessel invasion; the tumour mass had infiltrated more than two-thirds of the muscular uterine wall. The pathological stage of the tumour was pT1c Nx Mx: FIGO stage Ic.

The other findings of note were moderate hyperplasia of the squamous epithelia of the ectocervix, low-degree chronic cervical inflammation, a nabothian cyst, chronic salpingitis, a cystic follicle and corpora albicantia ovariarum.

The surgery and postoperative recovery were unremarkable. The patient was released from the clinic and

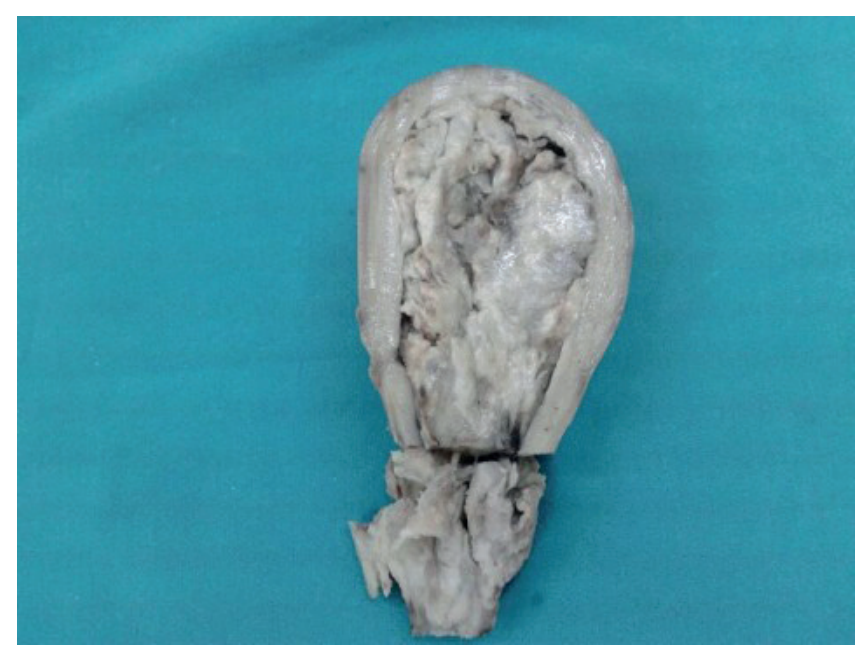

Image 3. A histopathological uterine preparation (longitudinal section) showing that the tumour mass filled the cavum sent to the Department of Oncology at the Radiology and Oncology Insitut of Serbia.

There, the patient received postoperative radiotherapy of the small pelvis with TD 46 Gy in 22 fractions (after taking into consideration the last dose received after Ro castration) with the "Izocentre techniqie" in combination with brachytherapy for a TD of 24 Gy (4 x 600 cGy via a vaginal cylinder).

The described therapy was subjectively and haematologically well received, with the only side effect being haemorrhoidal discomfort. Radiotherapy was administered at the planned dosages.

During her hospitalization in the Oncology and Radiology Institute of Serbia, abdominal and pelvic CT scans were performed, as well as US studies of the neck, abdomen, pelvis and ingvinum. The

CT scans showed pleural adhesions in the lung base. No abnormalities were observed in the liver, gallbladder, pancreas, kidneys or adrenal glands. The retroperitoneal and parailiac bilateral lymph nodes were all smaller than $10 \mathrm{~mm}$ in diameter. There were differentiated nodular formations of up to $5 \mathrm{~mm}$ in diameter, which corresponded to the mesentery lymph nodes. The urinary bladder showed no intraluminal vegetation. There has thus far been no evidence of recurrence. The ischiorectal region was fossa free, and the bilateral inguinal lymph nodes were all $10 \mathrm{~mm}$ or smaller in size.

The US studies showed a homogenic parahilar zone with many repaired parenchymal tissue and structural changes possibly resulting from the applied $\mathrm{TH}$. There was no ascites present. The biliary tract was free from pathological changes. Tracking the patient's liver condition is mandatory, and she will continue to be monitored. The pancreas, spleen, adrenal glands and urinary tract were all free from pathological changes. The postoperative scar was regular, clear, and free from signs of recidives. The rectum was normal. There were no pathological changes observed in the para aortocaval, parailiac, supraclavicular or spinal lymph nodes. The bilateral inguinal area had no pathological lymph nodes but did have reactive lymph nodes with a lipomatose appearance, which had a diameter up to $12 \mathrm{~mm}$.

The patient is regularly seen every three months for a follow-up examination. There have thus far been no signs of relapse. The gynaecological findings are normal. The last US findings of the abdomen and the small pelvis were normal. The results of the laboratory analysis were also within the normal limits. She continues to receive adjuvant therapy with Nolvadex. The values of Ca15-3 have been within the normal range.

\section{DISCUSSION}

Uterine adenosarcomas are relatively rare tumours, although their incidence appears to have increased in recent years. It is likely that this increase is due to a better un- 
derstanding of the different anatomical aspects of uterine sarcomas (especially after the introduction of immunohistochemical staining) and possibly due to the exposure of patients to predisposing factors, including pelvic irradiation and the use of tamoxifen for the treatment of breast cancer (20).

Although the full aetiology remains unknown, at least three possible risk factors are currently under consideration. These risk factors include pelvic irradiation, as some cases have been reported in patients with a history of previous pelvic irradiation (21); hyperestrogenism, where the tumours would have developed as a result of prolonged unbalanced oestrogen stimulation or a long period of oral contraceptive use (22); and tamoxifen treatment, because some cases have been reported in patients previous treated with tamoxifen for breast cancer (23).

Patients with uterine endometrial adenosarcomas have generally been postmenopausal, with the median age at presentation previously reported to be 58 years (24). The most common symptom is abnormal vaginal bleeding (71\%), spotting, menorrhagia or metrorrhagia, as in our patient. These tumours can present as a pelvic mass (37\%), uterine polyp (22\%), or an enlarged uterus (22\%) (25). Pain and the presence of a foul-smelling vaginal discharge or symptoms of pelvic pressure have also been reported. Deep myometrial invasion, as a predictor of aggressive behaviour, and sarcomatous overgrowth are the two most important predictors of a poor prognosis (2). Myometrial invasion is found in $15 \%$ of cases, but deep myometrial invasion is generally found only in $5 \%$ of cases (24). The presence of heterologous elements, especially rhabdomyosarcoma, may reflect a more clinically aggressive tumour. The immunophenotype of these tumours is similar to that of an undifferentiated uterine sarcoma, which usually have poor expression of the cell differentiation markers, the oestrogen receptor, progesterone receptor and CD10 (26). Mullerian adenosarcoma can be easily distinguished from adenofibroma (where both the epithelial and stromal components are benign) using the criteria defined as unique to adenosarcoma, such as a marked degree of atypia of mesenchymal cells, a histologically malignant element, the presence of myometrial invasion, and two or more mitotic figures per 10 HPF (27).

Nevertheless, these features are not always present. Thus, they are less applicable for the categorization of the degree of malignancy.

When treating these tumours, most authors recommend total abdominal hysterectomy usually accompanied by bilateral salpingo-oophorectomy (28). There is currently no consensus among gynaecologists on the value of staging by lymphadenectomy during primary surgery.

Generally, patients with tumours invading more than halfway through the myometrium, such as our patient, or with two or more unfavourable factors present have a high likelihood of recurrence and might benefit from high-dose pelvic radiation with or without aggressive chemotherapy (29).

\section{CONCLUSION}

The best approach for the management of uterine adenosarcomas has yet to be defined; surgery, chemotherapy, radiotherapy, and careful follow-up have all been used. In our case, surgery and postoperative radiotherapy with close follow-up seems to have been an appropriate course of action.

\section{CONFLICT OF INTEREST}

The authors declare no financial or commercial conflicts of interest.

\section{REFERENCES}

1. Singh R. Review literature on uterine carcinosarcoma. J Can Res Ther 2014;10:461-8.

2. McCluggage WG. Mullerian adenosarcoma of the female genital tract. Adv Anat Pathol. 2010 Mar;17(2):122-9.

3. F. Amant, E. Steenkiste, K. Schurmans, et al. Immunohistochemical expression of CD10 antigen in uterine adenosarcoma. Int J Gynecol Cancer, 14 (2004), pp. 1118-21.

4. D’Angelo E, Prat J. Pathology of mixed Müllerian tumours. Best Pract Res Clin Obstet Gynaecol. 2011 Dec;25(6):705-18.

5. Chaudhary YS, Illahi F, Moatasim A. Carcinosarcoma uterine unusual histologic presentation. Rawal Med J 2009;34:120-2.

6. Wolfson AH, Wolfson DH, Sittler SY, Breton L, Markoe AM, Schwade JG, et al. A multivariate analysis of clinicopathologic factors for predicting outcome in uterine sarcomas. Gynecol Oncol 1994;52:56-62

7. Yildirim Y, Inal MM, Sanci M, Yildrim YK, Mit T, Polat $\mathrm{M}$, et al. Development of uterine sarcoma after tamoxifen treatment for breast cancer: A report four cases. Int J Gynecol Cancer 2005;15:1239-42.

8. Arenas M, Rovirosa A, Hernandez V, Ordi J, Jarcano S, Mellado B, et al. Uterine sarcomas in breast cases patients treated with tamoxifen. Int J Gynecol Cancer 2006; $16: 861-5$

9. Wysowki DK, Honig SF, Beitz J. Uterine sarcoma associated with tamoxifen use. N Engl J Med 2002;346:1832-3.

10. Kloos I, Delaloge S, Pautier P, Di Palma M, Goupil A, Duvillard P, et al. Tamoxifen related uterine carcinosarcomas occur under/after prolonged treatment: Report of five cases and review of literature. Int J Gynecol Cancer 2002;12:496-500.

11. Hubalek M, Ramoni A, Muller-holzner E, Marth C. Malignant mixed mesodermal tumour after tamoxifen therapy for breast cancer. Gynecol Oncol 2004;95:264-6.

12. Ferguson SE, Tornos C, Hummer A, Barakat RR, Soslow RA. Prognostic features of surgical stage I uterine carcinosarcoma. Am J Surg Pathol 2007;31:1653-61. 
13. Ablen EC, Smit VT, Wessels JW, de Deleeuw WJ, Cornelisse CJ, Fleuren GJ. Molecular genetic evidence for the conversion hypothesis of the origin of malignant mixed Mullerian tumours. J Pathol 1997;183:424-31.

14. Kuyumcuoglu U, Kale A. Homologous type malignant mixed Mullerian tumour of the uterus presenting as cervical mass. J Chin Med Assoc 2009;72:533-5

15. Molpus KL, Redline-Frazier S, Reed G, Burnett LS, Jones HW 3 rd . Postoperative pelvic irradiation in early stage uterine mixed Mullerian tumours. Eur J Gynecol Oncol 1998;19:541-6.

16. Menczer J, Levy T, Piura B, Chetrit A, Altaraj M, Meirovitz $\mathrm{M}$, et al. A comparison between different postoperative treatment modalities of uterine carcinosarcoma. Gynecol Oncol 2005;97:166-70.

17. Wong L, See HT, Khoo-Tan HS, Low JS, Ng WT, Low JJ. Combined adjuvant cisplatin and ifosfamide chemotherapy and radiotherapy for malignant mixed Mullerian tumours of the uterine sarcomas. Int J Gynecol Cancer 2006;16:1364-9.

18. Felix AS1, Stone RA, Bowser R, Chivukula M, Edwards RP, Weissfeld JL, Linkov F. Comparison of survival outcomes between patients with malignant mixed mullerian tumors and high-grade endometrioid, clear cell, and papillary serous endometrial cancers. Int J Gynecol Cancer. 2011 Jul;21(5):877-84.

19. Tong SY1, Lee JM, Choi YJ, Lee JK, Kim JW, Cho CH, Kim SM, Park SY, Park CY, Kim KT. The comparison of clinicopathological characteristics in primary malignant mixed müllerian tumour with epithelial endometrial carcinoma. Aust N Z J Obstet Gynaecol. 2012 Feb;52(1):44-8.

20. Reed NS: Uterine sarcomas--the biggest challenge? Clin Oncol (R Coll Radiol) 2002, 14(1):50-3.
21. Norris HJ, Taylor HB: Postirradiation sarcomas of the uterus. Obstet Gynecol 1965, 26(5):689-94.

22. Press MF, Scully RE: Endometrial "sarcomas" complicating ovarian thecoma, polycystic ovarian disease and estrogen therapy. Gynecol Oncol 1985, 21(2):135-54.

23. Clement PB, Oliva E, Young RH: Mullerian adenosarcoma of the uterine corpus associated with tamoxifen therapy: a report of six cases and a review of tamoxifenassociated endometrial lesions. Int J Gynecol Pathol 1996, 15(3):222-9.

24. Clement PB, Scully RE: Mullerian adenosarcoma of the uterus: a clinicopathologic analysis of 100 cases with a review of the literature. Hum Pathol 1990, 21(4):363-81.

25. Verschraegen CF, Vasuratna A, Edwards C, Freedman R, Kudelka AP, Tornos C, Kavanagh JJ: Clinicopathologic analysis of mullerian adenosarcoma: the M.D. Anderson Cancer Center experience. Oncol Rep 1998, 5(4):939-44.

26. Gallardo A, Prat J: Mullerian adenosarcoma: a clinicopathologic and immunohistochemical study of 55 cases challenging the existence of adenofibroma. Am J Surg Pathol 2009, 33(2):278-88.

27. Zaloudek CJ, Norris HJ: Adenofibroma and adenosarcoma of the uterus: a clinicopathologic study of 35 cases. Cancer 1981, 1548(2):354-66.

28. Krivak TC, Seidman JD, McBroom JW, MacKoul PJ, Aye LM, Rose GS: Uterine adenosarcoma with sarcomatous overgrowth versus uterine carcinosarcoma: comparison of treatment and survival. Gynecol Oncol 2001, 83(1):89-94.

29. Clement PB, Scully RE: Müllerian adenosarcoma of the uterus. A clinicopathologic analysis of ten cases of a distinctive type of müllerian mixed tumor. Cancer 1974, 34(4):1138-49. 